Egyptian Journal of Aquatic Biology \& Fisheries

Zoology Department, Faculty of Science,

Ain Shams University, Cairo, Egypt.

ISSN $1110-6131$

Vol. 24(2): $301-316(2020)$

www.ejabf.journals.ekb.eg

\title{
Heavy Metal Concentration in White Shrimp Nematopalaemon hastatus and their Associated Ecological and Health Risk in the Nigerian Continental Shelf
}

\author{
Bayode P. Omobepade ${ }^{1 *}$, Ademola M. Akinsorotan ${ }^{1}$, Adefemi O. Ajibare ${ }^{2}$, \\ Eunice M. Ogunbusola ${ }^{3}$, Tolulope O. Ariyomo ${ }^{1}$, Jeremiah O. Jimoh $^{1}$, \\ Kemisola M. Odeyemi ${ }^{1}$, Onyinye S. Okeke ${ }^{1}$, Michael A. Falabake ${ }^{3}$ \\ Segun M. Adeniji ${ }^{1}$ and Akinola M. Adedapo ${ }^{1}$
}

\author{
${ }^{1}$ Department of Fisheries and Aquaculture, Federal University Oye-Ekiti, Nigeria, \\ ${ }^{2}$ Department of Fisheries and Aquaculture, Olusegun Agagu University of Science and \\ Technology Okitipupa, Nigeria, \\ ${ }^{3}$ Department of Food Science and Technology, Federal University Oye-Ekiti, Nigeria \\ "Corresponding Author: bayode.omobepade@fuoye.edu.ng
}

\section{ARTICLE INFO \\ Article History: \\ Received: Feb. 26, 2020 \\ Accepted: April 28, 2020 \\ Online: May 2020}

\section{Keywords:}

Heavy metal; health quotient; ecological risk index; white shrimp; supply chain

\begin{abstract}
Attaining shrimp safety and quality management in developing countries entails the assessment of parameters that determines their level for consumption. Hence, the heavy metal concentration in white shrimp (Nematopalaemon hastatus) collected along the supply in the continental shelf of Nigeria and their associated health and ecological risk were evaluated using standard methods. Results indicated that Zinc was the highest $\left(19.38 \mathrm{mgkg}^{-1}, 56.57 \mathrm{mgkg}^{-1}\right.$ and $\left.56.64 \mathrm{mgkg}^{-1}\right)$ heavy metal in the samples collected at landing, processing and marketing segments of the supply chain respectively. The study further indicated that the health quotient and ecological risk index for all the heavy metals evaluated in the $N$. hastatus had values that were less than one (1). This implies that the entire population would not experience the hazard of heavy metal $(\mathrm{Cd}, \mathrm{Cu}, \mathrm{Fe}, \mathrm{Pb}, \mathrm{Ni}$, $\mathrm{Mn}$, and $\mathrm{Zn}$ ) in later life due to the consumption of $N$. hastatus. It equally indicated that the shrimp posed no ecological risk in the Nigerian continental shelf. Hence, the entire human population who consumes/utilize $N$. hastatus can continually depend on the supply of safe $N$. hastatus from the Nigerian continental shelf. The study recommends increased utilization of white shrimp in value-added food products to sustain/attain healthy living and promotion of well-being in Nigeria and in other developing nations.
\end{abstract}

\subsection{INTRODUCTION}

Shrimp are highly-priced seafood harvested from coastal tropical and warmtemperature waters and they support commercially valuable fisheries in many areas of the world (Ajani et al., 2013). Due to industrialization and agricultural production, most water bodies that serve as the source of these shrimps most especially in developing 
countries are continuously been contaminated with heavy metal release (Oluyemi and Olabanji et al., 2011). Hence the threat of metal toxicity to the ecosystem and human population is of great concern (Abubakar et al., 2015). Different species of shrimps are available on the continental shelf of developing countries. Olawusi-Peters et al. (2014) documented that the abundance of species such as African giant shrimp (Parapenaeopsis atlantica), Red shrimp ( $P$. longirostris) and white shrimp (Nematopalaemon hastatus) in Nigeria is of great commercial importance in the country' s continental shelf that cuts across nine states (Akwa-Ibom, Bayelsa, Cross River, Delta, Edo, Lagos, Ogun, Ondo and Rivers) of the federation. However, their utilization and contribution to healthy living are largely influenced by their safety level. This is because they bioaccumulate heavy metals much higher than the level present in the water body and sediments (Abubakar et al., 2015). Because of this ecological attribute, a lot of research has been conducted to evaluate the levels of heavy metals in shrimps and other kinds of seafood.

Nematopalaemon hastatus (Aurivillius, 1898) is an important component of the global shrimp supply; most especially in developing countries where it is a major protein source in the diets of coastal and inland inhabitants (Akinwumi et al., 2011 and Ajibare et al., 2018). They are mostly consumed in developing countries in whole dried and powdered form and used in flavouring different types of food including its utilization in the production of weaning diets (Ajala and Oyategbe, 2013 and Shehu et al., 2013). Its supply passes through a similar supply chain for aquatic products (Bolwig et al., 2008; Christensen et al, 2010; Matarr et al., 2010; Macfadyen et al., 2011; Navghan et al., 2017).

The continuous utilization of the shrimp is, however, a function of their heavy metal concentration as well as the health and ecological risk they pose to human population and aquatic ecosystems (Baboli and Velayatzadeh, 2013; Balfour et al., 2014, Abubakar et al. 2015; Gendy et al., 2015). Such parameters are used globally in setting standards, controlling quality and checking population status in an aquatic environment (World Health Organization, 2005; Food and Agriculture Organization, 2007). Institutions such as the Food and Agriculture Organization (FAO), the United Nations Environmental Protection Agency (UNEPA) and the World Health Organization (WHO) have set safe limits for heavy metals in food and water (WHO, 2005; FAO, 2007). In Nigeria, considerable work has been done on the levels of heavy metals in aqua foods from fresh and marine waters (Ajala and Oyategbe, 2013; Bello, 2013; Shehu et al., 2013; Udo and Opeh, 2013; Ajibare et al., 2018). However, there is inadequate information on the safety levels of the heavy metals in $N$. hastatus collected along the supply chain in the Nigerian continental shelf.

Therefore, this article aims at providing information on the level of heavy metals in the shrimp species and their associated health and ecological risks. This would assist existing and prospective consumers in Nigeria and other developing countries who intend 
to source the shrimp species from the different segments of the supply chain to become aware of its safety for consumption. This is very important for developing countries that are currently striving to ensure healthy living and promotion of well-being for all ages; one of the cardinal objectives of the sustainable development goals (United Nations Development Programme, 2015).

\subsection{MATERIALS AND METHODS}

\subsection{Description of Study Area}

This study was conducted in the Ondo State axis of the Nigerian continental shelf (Fig.1). The area has a coastline of about $180 \mathrm{~km}$ that empties into the Atlantic Ocean which lies on longitude $5^{\circ}$ east to the Nigerian/Cameroon border. It is located at the extreme southern part of Ondo State, South West, Nigeria on Latitudes $6.00^{\circ} \mathrm{N}$ and $6^{\circ} 30^{1} \mathrm{~N}$ and Longitudes $4^{\circ} 45^{1} \mathrm{E}$ and $5^{\circ} 45^{1}$. It covers an area of $1,318 \mathrm{~km}^{2}$ with a human population of 290,615 (National Population Census, 2006). The major occupation of the people in the area is artisanal fishing on the sea, fish processing and marketing, canoe building, lumbering, farming and petty trading while the major form of transportation is motorized boats and paddled canoe (Bayode et al., 2011 and Alhaji et al., 2015). Solarin et al. (2010) documented that the area is rich in aquatic resources such as fish, shellfish, reptiles and other biodiversity; most importantly the abundance of White shrimp (Nematopalaemon hastatus) with a $75 \%$ frequency of occurrence in shrimp landings (Olawusi-Peters and Ajibare, 2014).

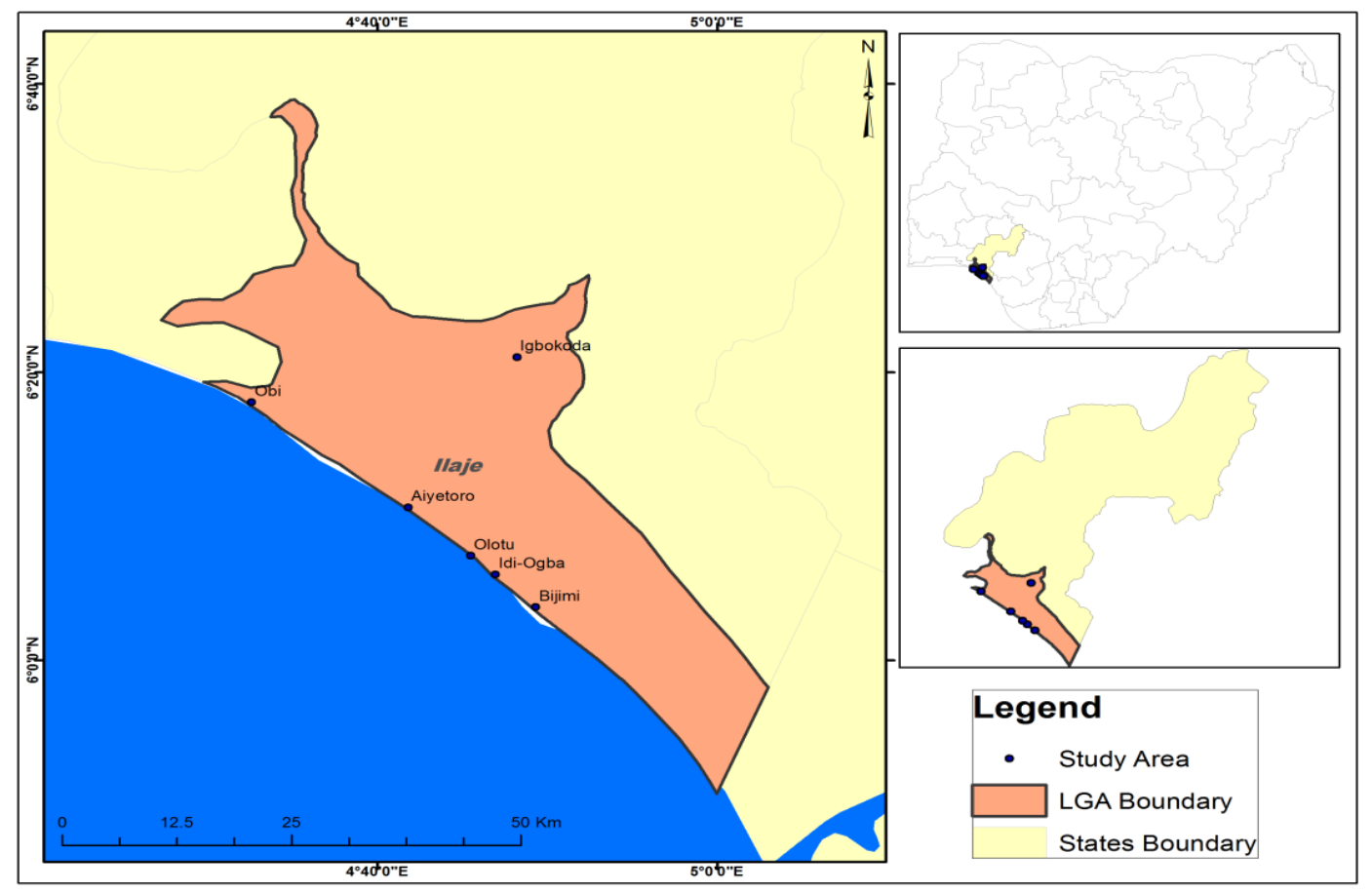

Fig 1. Map Showing Locations where shrimp samples were collected 


\subsection{Sample Collection}

White shrimp samples were collected along the three stages (landing, processing, and marketing) of the supply chain in the Ondo State axis of the Nigerian continental shelf between January and February 2018. Four communities (Ayetoro, Bijimi, Igbokoda and Obi) that were prominent in shrimping, processing and marketing of the shrimp species in the State were purposely selected for this study. Fresh samples caught by artisanal shrimpers on the Nigerian Continental Shelf using stow net and dried via traditional smoking method were collected randomly from the landing and processing sites at Ayetoro $\left(6.1086^{\circ} \mathrm{N}\right.$ and $\left.4.7711^{\circ} \mathrm{E}\right)$ and Bijimi $\left(6.0619^{\circ} \mathrm{N}\right.$ and $\left.4.8217^{\circ} \mathrm{E}\right)$ respectively. Market samples were collected from Igbokoda $\left(6.3529^{\circ} \mathrm{N}\right.$ and $\left.4.8063^{\circ} \mathrm{E}\right)$ and Obi $\left(6.2995^{\circ} \mathrm{N}\right.$ and $\left.4.5400^{\circ} \mathrm{E}\right)$. The fresh shrimp samples were preserved in ice and frozen in the refrigerator at $-4^{\circ} \mathrm{C}$ while samples collected from the processing and marketing areas were kept in desiccators pending laboratory analysis.

\subsection{Determination of Heavy Metals and their Associated Health and Ecological Risks}

Whole white shrimp samples collected from the different points of the supply chain were dried at $110^{\circ} \mathrm{C}$ for 48 -h. They were digested in a flask containing $2 \mathrm{ml}$ nitric acid and $1 \mathrm{ml}$ of chloric acid for $3 \mathrm{~h}$ at $120^{\circ} \mathrm{C}$. Digested samples were then diluted with distilled water in the range of standards that were prepared from the stock standard solution of the metals to be measured. After the dilution, heavy and trace metals such as cadmium, calcium, copper, iron, magnesium, manganese, nickel, potassium, sodium and zinc were measured in $\mathrm{mgkg}^{-1}$ using atomic absorption spectrometer (model: CELiL, CE2021 U.K). The health risk associated with the heavy metals was assessed by considering the whole white shrimp. This is because they are mostly consumed in the study area and in other developing nations in the whole/powdered form (Bello, 2013). Indices used include ecological risk index, health quotient and health risk index which were determined according to methods described by Sajjad et al., (2009), Okunola et al., (2011) and Abubakar et al., (2014). Health quotient describes the risk associated with the intake of heavy metal in $N$. hastatus. It estimates the hazard heavy metal in the shrimp could have on the human population in their later life. It was determined according to the formula in equation 1:

$\mathrm{HQ}=\frac{\text { Wprawn } \times \text { Mprawn }}{\text { RfD } \times \text { Bo }}$

Where: Wprawn is the dry weight of the prawn consumed per/day, Mprawn is the concentration of heavy metal in the species in $\mathrm{mg} / \mathrm{kg}$, RfD is the reference daily dose $\left(\mathrm{mgkg}^{-1} \mathrm{~d}^{-1}\right)$ for cadmium $\left(3.0 \times 10^{-3}\right)$, copper $\left(4.0 \times 10^{-2}\right)$, iron $\left(7.0 \times 10^{-1}\right)$, lead $\left(4.0 \times 10^{-2}\right)$, nickel $\left(2 \times 10^{-2}\right)$, manganese $\left(1.4 \times 10^{-1}\right)$ and Zinc $\left(3.0 \times 10^{-1}\right)$ while $\mathrm{B}_{\mathrm{o}}$ is the average weight of the population. For this study an average of $50 \mathrm{~g}, 75 \mathrm{~g}$ and $100 \mathrm{~g}$ were recommended as the daily nutritional intake of the prawn for children $(0-15 \mathrm{~kg})$ between 0 and 5 years, teenagers $(45 \mathrm{~kg})$ between 6 and 17 years and adults $(65 \mathrm{~kg})$ who are above 18 years old respectively. To determine the health risk index, the daily intake of metals (DIM) was first determined according to equation 2 : 
$\mathrm{DIM}=\frac{\text { Cmetal } \times \text { Dprawn } \times \text { Cfactor }}{\text { Bo }}$

Where Cmetal is the heavy metal in white shrimp in $\mathrm{mgkg}^{-1}$, Dprawn is the nutritional intake of prawn $\left(\mathrm{gday}^{-1}\right)$, Cfactor is the conversion ratio of fresh to dry weight of $N$. hastatus. A value of 4.75 was computed according to the methods described by Abubakar et al. (2014) and the United States Environmental Protection Agency (2008). The health risk quotient was then calculated as the ratio of the daily intake of metals and the reference oral dose as presented in equation 3. Also, the ecological risk quotient presented in equation 4 measures the risk of heavy metal as an indicator of environmental pollution according to methods described by Isibor and Imoobe (2017).

$\mathrm{HRI}=\frac{\mathrm{DIM}}{\mathrm{RfD}}$

$\mathrm{ERQ}=\frac{\text { Mprawn }(\mathrm{mg} / \mathrm{kg})}{\text { Recommended Limit }(\mathrm{mg} / \mathrm{kg})}$

\subsection{Statistical Methods}

The heavy metal concentration was analyzed by a one-way analysis of variance using the statistical analysis system (University Version). The means and standard error were then separated using Duncan's multiple range test at a probability level of $\leq 0.05$. Means of the health quotient, health risk index and ecological risk quotient were presented in tables and a figure.

\subsection{RESULTS}

\subsection{Heavy Metals and Mineral Concentration in White shrimp at Segments}

The Trace and heavy metal concentration in $N$. hastatus collected along the supply chain segments is presented on Table 1 . The metals in samples collected at landing were in the following ascending order: $\mathrm{Mn}^{2+}<\mathrm{Ni}<\mathrm{Cd}<\mathrm{Cu}<\mathrm{Pb}<\mathrm{Mg}^{2+}<\mathrm{Fe}^{2+}<\mathrm{K}^{+}<$ $\mathrm{Na}^{2+}<\mathrm{Ca}^{2+}<\mathrm{Zn}^{2+}$ while metals in white shrimp collected from processing and marketing sites were in the following descending order: $\mathrm{Zn}^{2+}>\mathrm{Ca}^{2+}>\mathrm{Na}^{2+}>\mathrm{K}^{+}>\mathrm{Mg}^{2+}>\mathrm{Fe}^{2+}>\mathrm{Pb}$ $>>\mathrm{Mn}^{2+}>\mathrm{Cd}>\mathrm{Ni}>\mathrm{Cu}$. Cadmium in samples taken at landing $\left(0.002 \mathrm{mgkg}^{-1}\right)$, processing $\left(0.003 \mathrm{mgkg}^{-1}\right)$ and marketing areas $\left(0.003 \mathrm{mgkg}^{-1}\right)$ were not significantly different from each other. Copper in samples collected from processing $\left(0.0023 \mathrm{mgkg}^{-1}\right)$ and marketing $\left(0.0024 \mathrm{mgkg}^{-1}\right)$ stages showed no significant differences $(\mathrm{p}>0.05)$ but however significantly higher $(\mathrm{p}<0.05)$ than the $\mathrm{Cu}$ in fresh shrimp collected at landing $\left(0.0013 \mathrm{mgkg}^{-1}\right)$.

Equally, the Iron concentration in fresh samples taken at landing $\left(0.0215 \mathrm{mgkg}^{-1}\right)$ was significantly lower $(\mathrm{p} \leq 0.05)$ than the values recorded in samples collected from processing $\left(0.0577 \mathrm{mgkg}^{-1}\right)$ and marketing $\left(0.0575 \mathrm{mgkg}^{-1}\right)$ areas respectively. Lead was also similar $(\mathrm{p}>0.05)$ in samples collected at processing and marketing $(0.025 \mathrm{mg} / \mathrm{kg}) \mathrm{but}$ 
significantly higher than $\mathrm{Pb}$ in fresh samples $(0.016 \mathrm{mg} / \mathrm{kg})$. Results further indicated that Nickel concentration was significantly higher $(\mathrm{p}<0.05)$ in samples collected at processing and marketing stages $\left(0.0025 \mathrm{mgkg}^{-1}\right)$ than the value recorded at landing $\left(0.0013 \mathrm{mgkg}^{-1}\right)$. Manganese concentration in white shrimp collected at processing and marketing points $\left(0.0062 \mathrm{mgkg}^{-1}\right)$ showed no significant differences $(\mathrm{p}>0.05)$ but was significantly higher $(\mathrm{p}<0.05)$ than the $\mathrm{Mn}^{2+}$ in. hastatus at collected at landing $\left(0.0007 \mathrm{mgkg}^{-1}\right)$.

Statistically, the concentration of zinc in fresh $N$. hastatus at landing $\left(19.38 \mathrm{mgkg}^{-}\right.$ $\left.{ }^{1}\right)$ was significantly lower than the concentration in samples collected at processing (56.57 $\mathrm{mgkg}^{-1}$ ) and marketing (56.64 $\left.\mathrm{mgkg}^{-1}\right)$ stages. Other minerals such as calcium were found to be lowest in fresh shrimp at landing $\left(21.46 \mathrm{mgkg}^{-1}\right)$ compared with the non-significant values in samples collected from the processing $\left(40.68 \mathrm{mgkg}^{-1}\right)$ and marketing $\left(40.49 \mathrm{mgkg}^{-}\right.$ $\left.{ }^{1}\right)$ stages of the supply chain. Magnesium was found to be lowest in fresh $N$. hastatus $\left(0.02 \mathrm{mgkg}^{-1}\right)$ compared with values recorded in dried samples collected from the processing and marketing $\left(0.23 \mathrm{mgkg}^{-1}\right)$ stages of the supply chain. The amount of potassium in samples collected at processing $\left(6.56 \mathrm{mgkg}^{-1}\right)$ and marketing $\left(6.57 \mathrm{mgkg}^{-1}\right)$ segments of the supply chain were higher than the value recorded in fresh $N$. hastatus at landing $(0.25 \mathrm{mg} / \mathrm{kg})$. The trend of differences between samples collected at different samples was also reflected in the amount of sodium available in samples along the supply chain. $\mathrm{Na}^{+}$in fresh shrimp at landing $(1.15 \mathrm{mgkg}-1)$ was significantly lower than the values recorded in samples collected at the processing $\left(19.68 \mathrm{mgkg}^{-1}\right)$ and marketing $\left(19.64 \mathrm{mgkg}^{-}\right.$ $\left.{ }^{1}\right)$ segments.

\subsection{Health and Ecological Risk Index of Heavy Metals in N. hastatus}

The health and ecological risk index of heavy metals in $N$. hastatus collected from the study area are presented in Table 2 and Fig 2 respectively. Table 2 reveals that the children population ( $<5$ years) had the highest health quotient and health risk index for all the heavy metals measured. The HQ for the children was 0.0016, 0.003, 0.000, 0.003, 0.001, 0.000 and 0.005 for $\mathrm{Cd}, \mathrm{Cu}, \mathrm{Fe}, \mathrm{Pb}, \mathrm{Ni}, \mathrm{Mn}$ and $\mathrm{Zn}$ respectively. This was followed by the population that ranged between 6 and 17 years old. The population above 18 years old had the least HQ for the metals. The health risk index reflected an individual' $\mathrm{s}$ risks of heavy metal exposure based on average body weight relative. The results showed that the HRI for cadmium in the three age categories were well above one (1) with values ranging from 14.620 in the category of the age group of $\geq 18$ years $(66 \mathrm{~kg})$ to 31.670 in the age group $\leq 5$ years $(14 \mathrm{~kg})$. A similar trend was observed for copper $(\mathrm{Cu})$ where all HRI values were above one (1) with lowest and highest values of 2.375 and 5.146 observed in age groups of $\geq 18$ years $(66 \mathrm{~kg})$ and $\leq 5$ years $(14 \mathrm{~kg})$ respectively. 
Table 1: Heavy Metals and Mineral Concentration in White shrimp along Stages of the Supply Chain

\begin{tabular}{lcccc}
\hline $\begin{array}{l}\text { Metals } \\
(\mathbf{m g} / \mathbf{k g})\end{array}$ & Landing & Processing & Marketing & $\begin{array}{c}\text { WHO } \\
\text { Recommended } \\
\text { Value }\end{array}$ \\
\hline Cadmium & $0.0020 \pm 0.000^{\mathrm{a}}$ & $0.0030 \pm 0.000^{\mathrm{a}}$ & $0.0030 \pm 0.000^{\mathrm{a}}$ & 0.50 \\
Copper & $0.0130 \pm 0.0132^{\mathrm{a}}$ & $0.0023 \pm 0.0003^{\mathrm{b}}$ & $0.0024 \pm 0.0131^{\mathrm{b}}$ & 3.00 \\
Iron & $0.0215 \pm 0.0215^{\mathrm{a}}$ & $0.0577 \pm 0.0021^{\mathrm{b}}$ & $0.0575 \pm 0.0019^{\mathrm{b}}$ & 0.50 \\
Lead & $0.0160 \pm 0.0030^{\mathrm{a}}$ & $0.0250 \pm 0.0020^{\mathrm{b}}$ & $0.0250 \pm 0.0020^{\mathrm{b}}$ & 2.00 \\
Nickel & $0.0013 \pm 0.0002^{\mathrm{a}}$ & $0.0026 \pm 0.0001^{\mathrm{b}}$ & $0.0026 \pm 0.0001^{\mathrm{b}}$ & 0.20 \\
Manganese & $0.0007 \pm 0.0004^{\mathrm{a}}$ & $0.0062 \pm 0.0003^{\mathrm{b}}$ & $0.0062 \pm 0.0004^{\mathrm{b}}$ & 0.50 \\
Zinc & $19.3800 \pm 0.1500^{\mathrm{a}}$ & $56.5700 \pm 0.1200^{\mathrm{b}}$ & $56.64 \pm 0.12000^{\mathrm{b}}$ & 30.00 \\
\hline Minerals & & & & \\
\hline Calcium & $21.4900 \pm 0.0500^{\mathrm{a}}$ & $40.6800 \pm 0.0600^{\mathrm{b}}$ & $40.4900 \pm 0.0400^{\mathrm{b}}$ & \\
Magnesium & $0.0189 \pm 0.0002^{\mathrm{a}}$ & $0.2278 \pm 0.0002^{\mathrm{b}}$ & $0.2274 \pm 0.0001^{\mathrm{b}}$ & \\
Potassium & $0.2549 \pm 0.0005^{\mathrm{a}}$ & $6.5625 \pm 0.0006^{\mathrm{b}}$ & $6.5657 \pm 0.0009^{\mathrm{b}}$ & \\
Sodium & $1.1564 \pm 0.0004^{\mathrm{a}}$ & $19.6800 \pm 0.0021^{\mathrm{b}}$ & $19.6400 \pm 0.0023^{\mathrm{b}}$ & \\
\hline
\end{tabular}

Mean \pm S.E with different superscripts along rows are significantly different from each other $(\mathrm{p}<0.05)$

HRI for Fe was lower than one (1) in an individual with an average weight of $66 \mathrm{~kg}$ $(0.225)$ and $44 \mathrm{~kg}(0.243)$ but was higher than one (1) in an individual having an average weight of $14 \mathrm{~kg}$ (4.863). The values of HRI for $\mathrm{Pb}$ were all higher than one (1) in the three categories of age group as shown in Table 4. The table shows that HRI for $\mathrm{Pb}$ was 2.923 , 3.167 and 6.333 in categories of $66 \mathrm{~kg}$ ( $\geq 18$ years), $44 \mathrm{~kg}$ (6-17 years) and $14 \mathrm{~kg}$ ( $\leq 5$ years) respectively. Also, HRI for Mn was lower than one (1) in individuals of the average weight of $66 \mathrm{~kg}$ ( $\geq 18$ years) and $44 \mathrm{~kg}$ (6-17 years) with values of 0.037 and 0.040 respectively but was higher than one (1) in the category of $14 \mathrm{~kg}$ ( $\leq 5$ years). The Ecological risk quotient (Fig. 2) had a pattern of $\mathrm{Zn}>\mathrm{Fe}>\mathrm{Pb}>\mathrm{Ni}>\mathrm{Cu} \geq \mathrm{Cd}>\mathrm{Mn}$ that was similar trend to the mean concentration in the shrimp i.e. $\mathrm{Zn}>\mathrm{Fe}>\mathrm{Pb}>\mathrm{Ni} \geq \mathrm{Cu}>\mathrm{Mn}>\mathrm{Cd}$. This pattern shows that $\mathrm{Zn}(0.646)$ had the highest while the lowest was observed in Mn (0.001). 
Table 2: Health Risk Assessment of Heavy Metals in N. hastatus

\begin{tabular}{lccccc}
\hline Metal & Mean $\pm \mathbf{S E}(\mathbf{m g} / \mathbf{k g})$ & Individuals & AW & HQ & HRI \\
\hline Cadmium & $0.002 \pm 0.000$ & $\geq 18$ Years & $66 \mathrm{~kg}$ & 0.004 & 14.62 \\
& & $6-17$ Years & $44 \mathrm{~kg}$ & 0.005 & 15.83 \\
& & $\leq 5$ Years & $14 \mathrm{~kg}$ & 0.016 & 31.67 \\
\hline Copper & $0.013 \pm 0.013$ & $\geq 18$ Years & $66 \mathrm{~kg}$ & 0.001 & 2.375 \\
& & $6-17$ Years & $44 \mathrm{~kg}$ & 0.001 & 2.573 \\
& & $\leq 5$ Years & $14 \mathrm{~kg}$ & 0.003 & 5.146 \\
\hline Iron & $0.0215 \pm 0.022$ & $\geq 18$ Years & $66 \mathrm{~kg}$ & 0.000 & 0.225 \\
& & $6-17$ Years & $44 \mathrm{~kg}$ & 0.000 & 0.243 \\
& & $\leq 5$ Years & $14 \mathrm{~kg}$ & 0.000 & 4.863 \\
\hline Lead & $0.016 \pm 0.003$ & $\geq 18$ Years & $66 \mathrm{~kg}$ & 0.001 & 2.923 \\
& & $6-17$ Years & $44 \mathrm{~kg}$ & 0.001 & 3.167 \\
& & $\leq 5$ Years & $14 \mathrm{~kg}$ & 0.003 & 6.333 \\
\hline Nickel & $0.0013 \pm 0.000$ & 618 Years & $66 \mathrm{~kg}$ & 0.001 & 4.75 \\
& & $6-17$ Years & $44 \mathrm{~kg}$ & 0.000 & 5.146 \\
& & $\leq 5$ Years & $14 \mathrm{~kg}$ & 0.001 & 1.029 \\
\hline Manganese & $0.0007 \pm 0.000$ & 618 Years & $66 \mathrm{~kg}$ & 0.000 & 0.037 \\
& & 6 - 17 Years & $44 \mathrm{~kg}$ & 0.000 & 0.04 \\
& & $\leq 5$ Years & $14 \mathrm{~kg}$ & 0.000 & 7.916 \\
\hline Zinc & 19 Years & $66 \mathrm{~kg}$ & 0.119 & 472.1 \\
& & $6-17$ Years & $44 \mathrm{~kg}$ & 0.172 & 511.4 \\
& & $\leq 5$ Years & $14 \mathrm{~kg}$ & 0.005 & 1023 \\
\hline
\end{tabular}

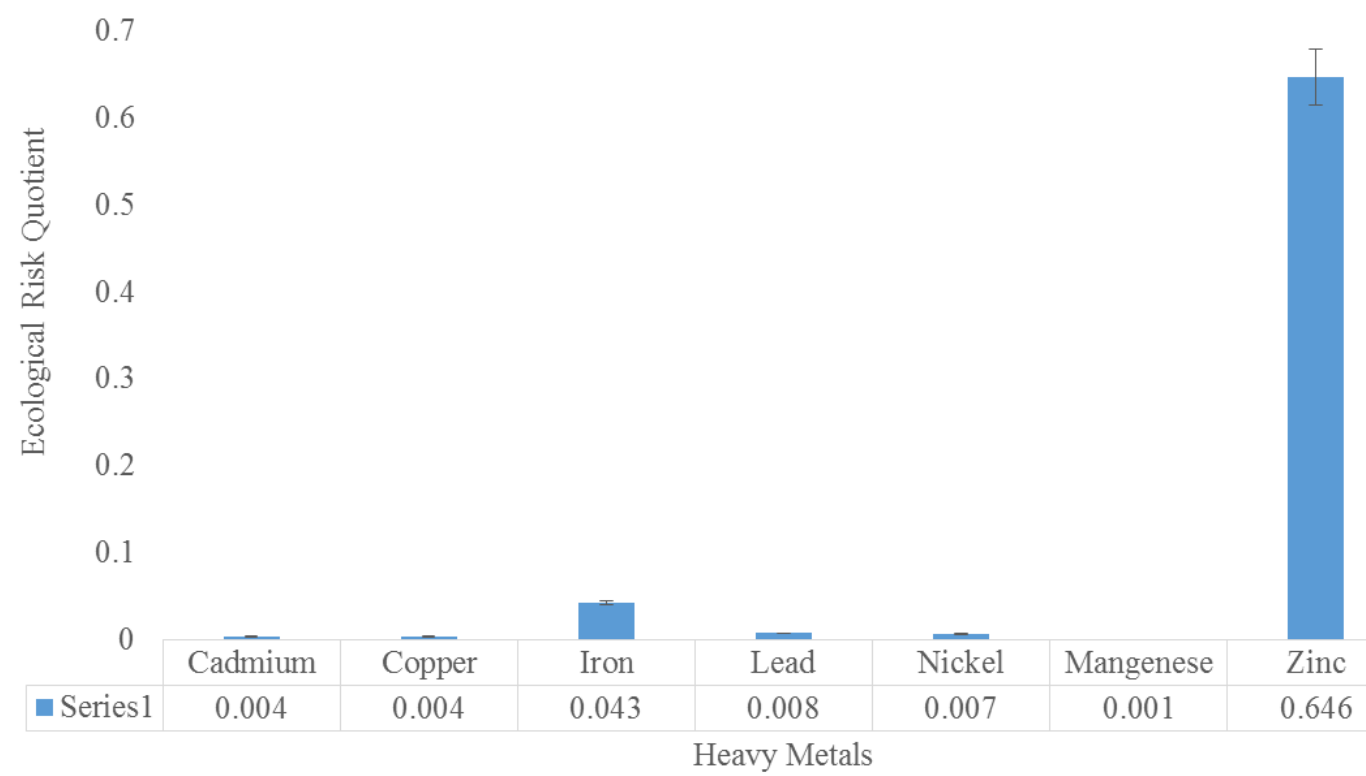

Fig 2: Ecological Risk indices of pollutants 


\subsection{DISCUSSION}

\subsection{Heavy Metals and Mineral Concentration in White shrimp at Segments}

The detection of low cadmium concentration along the three stages of the shrimp supply chain could be attributed to the less agricultural and industrial activities which have been identified as a major source of wide dispersion into the aquatic environment (Şireli $\boldsymbol{e} t$ al., 2006). Results from this study indicated that the values of $\mathrm{Cd}$ recorded in samples along the supply chain were lower than the levels $\left(0.5 \mathrm{mgkg}^{1}\right.$ and $\left.0.2 \mathrm{mgkg}^{-1}\right)$ recommended by WHO (2005) and FAO (2007) for consumption in shrimps. Moreover, similar studies in P. martia, P. edwardsii and A. antennatus (Olgunoglu et al. 2015) and P. semisulcatus (Heidarieh et al., 2013) did not detect Cadmium. However, $\mathrm{Cd}$ was discovered in other shrimp species reported by different authors across the world. Gokoglu et al. (2012) recorded a $2.36 \mathrm{mgkg}^{-1}$ of $\mathrm{Cd}$ in $P$. semisulcatus; $0.23-0.79 \mathrm{mgkg}^{-1}$ in P. longirostris; (Gokoglu et al. 2008 and Kulcu et al. 2014); $0.88 \mathrm{mg} / \mathrm{kg}$ in $P$. serratus (Kulcu et al. 2014) and $1.56 \mathrm{mkg}^{-1}$ in $P$. martia (Oksuz et al., 2009). Similarly, the amount of copper measured in the samples was lower than the maximum value $20 \mathrm{mgk}^{-1}$ and $3.0 \mathrm{mgkg}^{-1}$ recommended for human consumption by the Turkish Food Legislation (Baboli and Valeyatzadey, 2013) as well as WHO (2005) and FAO (2007). Such a trace amount recorded in the shrimp samples could assist consumers in carbohydrate metabolism and the functioning of more than 30 enzymes in the human body (Camara et al., 2005).

Iron concentration in fresh samples taken at landing $\left(0.0215 \mathrm{mgkg}^{-1}\right)$ was significantly lower $(\mathrm{p} \leq 0.05)$ than the values recorded in samples collected from processing $\left(0.0577 \mathrm{mgkg}^{-1}\right)$ and marketing $\left(0.0575 \mathrm{mgkg}^{-1}\right)$ areas respectively. This might be attributed to the reduction in the moisture content of the samples. Iron contents in the samples along the supply chain were lower than the $\mathrm{Fe}^{2+}$ reported by Baboli and Velayatzadey (2013) in F. merguiensis $\left(15.13 \mathrm{mgkg}^{-1}\right), P$. martia $\left(0.456 \mathrm{mgkg}^{-1}\right)$, P.edwardsii $\left(0.619 \mathrm{mgkg}^{-1}\right)$ and A. antennatus $\left(1.609 \mathrm{mgkg}^{-1}\right)$. Iron in white shrimp below the recommended level $\left(0.50 \mathrm{mgkg}^{-1}\right)$ has different functions in the body (WHO, 2005; FAO, 2007). It serves as a carrier of oxygen to the tissues from the lungs by red blood cell haemoglobin, as a transport medium for electrons within cells, and as an integrated part of important enzyme systems in various tissues (Camara et al., 2005).

The low level of lead in the $N$. hastatus samples along the supply chain could be attributed to the low level of lead concentration in the marine ecosystems where the shrimp were harvested. This implies that the environment has not been polluted via boat exhaust systems, oil spills and other petroleum compounds from mechanized boats employed in fishing in the study area. This may equally arise from the fact that lead was only detected in trace amounts in their habitats or these elements are not biomagnified in tissues (Gendy et al., 2015). Comparatively, the level of lead recorded in all the samples along the supply chain were lower than the value $(2 \mathrm{mg} / \mathrm{kg})$ recommended by WHO (2005) and FAO 
(2007) and also different from $\mathrm{Pb}$ reported by Olgunoglu et al. (2015), Kulcu et al. (2015), Udo and Opeh (2015) and Tawfik et al. (2013) in Aristaemorpha foliciacea $(0.43 \mathrm{mg} / \mathrm{kg})$, Merlicertus kerathurus $(4.26 \mathrm{mg} / \mathrm{kg})$, Macrobranchium vollenhovennii $(0.01 \mathrm{mg} / \mathrm{kg})$, Macrobranchium rosenbergii $(0.133 \mu \mathrm{g} / \mathrm{g})$, raw and cooked Penaeus monodon $(0.008$ and $0.006 \mu \mathrm{g} / \mathrm{g}$ ).

The level of Nickel in $N$. hastatus collected at all the three stages were below the value $\left(0.05 \mathrm{mgkg}^{-1}\right)$ recommended by WHO (2005) and FAO (2007). This value was however higher than the Ni reported by Tawfik (2013) for fresh $\left(0.020 \mathrm{\mu gg}^{-1}\right)$ and cooked $\left(0.080 \mu \mathrm{gg}^{-1}\right)$ black tiger shrimp (P. monodon). The $\mathrm{Ni}$ recorded in all the samples were lower when compared with similar studies by Yarsan et al. (2014) and Soegianto and Hamami (2007) who reported higher $\mathrm{Ni}$ in $P$. semisulcatus $\left(0.52 \mathrm{mgkg}^{-1}\right)$ and $P$. merguiensis $\left(18.95 \mathrm{mgkg}^{-1}\right.$ ) respectively. Nickel is quite abundant in the Earth' $\mathrm{s}$ crust; it enters water surface from the dissolution of rocks and soils, biological cycles, atmospheric fallout, and especially from industrial processes and waste disposal and it does not display trends indicative of large anthropogenic contribution to the sediments (Gokoglu $\boldsymbol{e t}$ al. (2008). Therefore, the lower levels Ni recorded in samples at all the segments of the supply chain could be as a result of little or non-availability of activities that can increase $\mathrm{Ni}$ production as described by Gokoglu $\boldsymbol{e t}$ al. (2008).

Manganese at all the three segments of the supply chain was below the value $\left(0.05 \mathrm{mkg}^{-1}\right)$ recommended by WHO (2003) and FAO (2007). It was equally lower than the $\mathrm{Mn}^{2+}$ reported by Gokoglu et al. (2008) in Penaeus semisulcatus $\left(0.60 \mathrm{mgkg}^{-1}\right), 072-1.52 \mathrm{mgkg}^{-1}$ in Parapenaeuss longirostris (Oksuz et al. 2009), 0.25mgkg in Paleomonserratus (Gokogluet a 1. 2008), $50.5 \mathrm{mgkg}^{1}$ in Peneaus monodon (Dayal et al. 2013), $0.15 \mathrm{mgkg}^{-1}$ in $F$. merguiensis (Pournag and Amini, 2001), $0.17 \mathrm{mgkg}^{-1}$ in P. monodon (Bin-Mokhtar et al. 2009), $0.1 \mathrm{mgkg}^{-1}$ in F. merguiensis (Baboli and Velayatzadeh, 2013) and $0.14 \mathrm{mgkg}^{-1}$ in Plesionika martia (Oksuz et al. 2009).

Furthermore, the similarity in the concentrations of $\mathrm{Zn}$ at the processing and marketing stages of the white shrimp value chain is an indication that no significant $\mathrm{Zn}$ was lost between processing and marketing stages. Zn content recorded in shrimp collected at landing was below the value (30 $\left.\mathrm{mgkg}^{-1}\right)$ recommended by World Health Organization (2005) and Food Organisation (2007) but the value in samples at processing and marketing areas were however higher than the recommended admissible values by World Health Organization and the Food and Agriculture Organization. This implies that white shrimp is an excellent source of $\mathrm{Zn}$. Since $N$. hastatus is mostly consumed in smoked form, the increase in the value of $\mathrm{Zn}^{2+}$ in samples collected at the processing and marketing segments is significant for supplementing zinc-deficient diets (Tawfik, 2013).

Also, calcium recorded in all the samples were lower than the values reported by Bello (2013) in fresh $\left(1300 \mathrm{mgg}^{-1}\right)$, sundried $\left(1450 \mathrm{mgg}^{-1}\right)$, boiled $\left(1500 \mathrm{mgg}^{-1}\right)$ and smoked $\left(1150 \mathrm{mgg}^{-1}\right)$ P. notialis. Higher $\mathrm{Ca}^{2+}$ was equally reported by Dayal $\boldsymbol{e t}$ al. (2013) and Hog et 
al. (2006) in P. monodon $\left(107.3 \mathrm{mgg}^{-1}\right)$ and Metapenaus monoceros $\left(92 \mathrm{mgg}^{-1}\right)$ respectively. Magnesium in samples collected at the processing and marketing segments of the value chain was similar $\left(0.23 \mathrm{mgkg}^{-1}\right)$ and higher than the $\mathrm{Mg}^{2+}$ in the fresh samples $\left(0.02 \mathrm{mgkg}^{-1}\right)$. Equally, potassium was found to be significantly higher in dried samples collected at processing and marketing areas than $\mathrm{k}+$ recorded in fresh $N$. hastatus. A similar trend was reported for Sodium in the shrimp species in this study. The amount of $\mathrm{Mg}^{2+}$ reported in the samples along the supply chain was however lower when compared with similar studies conducted by Bello (2013) who reported higher $\mathrm{Mg}^{2+}$ in fresh $\left(540.33 \mathrm{mgg}^{-1}\right)$, sundried $\left(650 \mathrm{mgg}^{-1}\right)$, boiled $\left(570.35 \mathrm{mgg}^{-1}\right)$ and smoked $\left(515.23 \mathrm{mgg}^{-1}\right) P$. notialis. These values were lower compared with the $\mathrm{K}^{+}$reported by Bello (2013) in fresh $\left(350.75 \mathrm{mgg}^{-1}\right)$, sundried $\left(342.78 \mathrm{mgg}^{-1}\right)$, boiled $\left(335.75 \mathrm{mgg}^{-1}\right)$ and smoked $\left(250.50 \mathrm{mgg}^{-1}\right)$ in P. notialis. Also, $\mathrm{Na}^{+}$ recorded in the current study was lower when compared with the $\mathrm{Na}^{+}$reported by Bello (2013) in fresh P. notialis $\left(230.38 \mathrm{mgg}^{-1}\right)$, sundried $\left(240.35 \mathrm{mgg}^{-1}\right)$, boiled $\left(210.22 \mathrm{mgg}^{-1}\right)$ and smoked (245.35 $\left.\mathrm{mgg}^{-1}\right)$ P. notialis.

\subsection{Health and Ecological Risk Index of Heavy Metals in N. hastatus}

The Health quotient estimated for the three different populations in the later life for all metals and categories had values $(0.000-0.172)$ of less than one (1). This implies that the entire population would not experience the hazard of heavy metal $(\mathrm{Cd}, \mathrm{Cu}, \mathrm{Fe}, \mathrm{Pb}, \mathrm{Ni}, \mathrm{Mn}$, and $\mathrm{Zn}$ ) in later life due to the consumption of $N$. hastatus. Li et al. (2014) stated that a high value of hazard quotient poses relatively high potential health risks to human beings especially for those residing in areas with serious metal pollution. Onuoha et al., (2016) also reported that even though the HQ-based assessment method does not provide a quantitative estimate for the probability of an exposed population experiencing a reverse health effect, it indeed indicates the risk level due to exposure to pollutants.

The health risk index reflected an individual' $\mathrm{s}$ risks of heavy metal exposure based on average body weight relative. The results showed that the HRI for cadmium in the three age categories were well above one (1) with values ranging from 14.620 in the category of the age group of $\geq 18$ years $(66 \mathrm{~kg})$ to 31.670 in the age group $\leq 5$ years $(14 \mathrm{~kg})$. A similar trend was observed for copper $(\mathrm{Cu})$ where all HRI values were above one (1) with lowest and highest values of 2.375 and 5.146 observed in age groups of $\geq 18$ years $(66 \mathrm{~kg})$ and $\leq 5$ years $(14 \mathrm{~kg})$ respectively.

HRI for Fe was lower than one (1) in an individual with an average weight of $66 \mathrm{~kg}$ $(0.225)$ and $44 \mathrm{~kg}(0.243)$ but was higher than one (1) in individuals having an average weight of $14 \mathrm{~kg}$ (4.863). This implies that individuals of an average weight of $14 \mathrm{~kg}$ or aged 5 years and below that consume white shrimps from the coastal areas of Ondo state Nigeria would be exposed to a health hazard of Iron (Fe) in later life while others would benefit Iron nutrient from the consumption of $N$. hastatus (from the study area) as recommended for daily intake in this study. According to Isibor and Imoobe (2017), impermissible dietary levels of iron (Fe) 
may have many implications which include multi-system organ failures, convulsion, coma and ultimately death in man.

The values of HRI for $\mathrm{Pb}$ were all higher than one (1) in the three categories of age group as shown in Table 4. The table shows that HRI for Pb was 2.923, 3.167 and 6.333 in categories of $66 \mathrm{~kg}$ ( $\geq 18$ years), $44 \mathrm{~kg}$ (6-17 years) and $14 \mathrm{~kg}$ ( $\leq 5$ years) respectively. This observation is in line with Onuoha et al., (2016) who further stated that the ingestion of $\mathrm{Pb}$ through the consumption of food organisms may cause mental retardation among children and also hypertension in pregnant women. The values obtained for HRI of Nickel were also all above one (1) even though the value (1.029) obtained for the category of individuals with an average weight of $14 \mathrm{~kg}$ ( $\leq 5$ years) was slightly above one (1).

Also, HRI for Mn was lower than one (1) in individuals of the average weight of $66 \mathrm{~kg}$ ( $\geq 18$ years) and $44 \mathrm{~kg}$ (6-17 years) with values of 0.037 and 0.040 respectively but was higher than one (1) in the category of $14 \mathrm{~kg}$ ( $\leq 5$ years). This implies that the children (of the study area or) who consume the shrimp species under study are exposed to the health risk of manganese. According to Isibor and Imoobe (2017), excess consumption of manganese will cause poor cognitive performance in school children and neurological disorders similar to Parkinson's disease. The results of HRI for $\mathrm{Zn}$ had values that were far greater than one (472.1 in $\geq 18$ years -1023.0 in $\leq 5$ years). This implies that any individual that consumes $N$. hastatus from the study area is exposed to the health risk of $\mathrm{Zn}$.

Finally, for hazard quotient, the results proved that the ratios of heavy metals $(\mathrm{Cd}, \mathrm{Cu}, \mathrm{Fe}$, $\mathrm{Pb}, \mathrm{Ni}, \mathrm{Mn}$, and $\mathrm{Zn}$ ) were below the value of one (1) and this means that these metals would not pose any serious health hazards on the consuming population in the later life. Whereas, HRI revealed that the consumers of shrimps from the study area would be exposed to a high loading dose of cadmium, copper, lead, nickel, and zinc at all levels while only the groups of children $(\leq 5$ years $/ 14 \mathrm{~kg}$ ) would experience the impact of iron and manganese. These are at variance with the findings of Abubakar et al., (2014) who observed HQ values higher than one (1) and HRI values of less than one (1) for the muscle/tissue of imported frozen fish Trachurus Murphyi species sold in Zaria metropolis, Nigeria.

Results of the ecological risk indices showed that $N$. hastatus in this study posed no ecological risk to the environment since all the observed values were significantly less than one (1). Also, shrimps are organisms that are naturally rich in Zinc (Ajibare et al., 2018), hence the high (but permissible) concentration was not a surprise. Abubakar et al., (2014) reported that human activities such as industrial, agricultural and domestic activities may render a high concentration of heavy metals in the water body. In this study, the levels of the examined heavy metal in $N$. hastatus were considerably lower than the safety limits recommended by World Health Organization (2005) thus the study area can be considered to be ecologically stable. However, the fact that all examined metals were detected in the shrimp species is an indication that the study area is under stress since the physiochemistry of 
an aquatic environment is the background factor that influences the kinetics of heavy metals (Ajibare, 2018).

\subsection{CONCLUSION}

This study provided information on heavy metals concentration in white shrimp and their associated ecological and health risk for existing and prospective processors, consumers and feed manufacturers who desire to buy the species at any of the segments of the supply chain in the Ondo axis of the Nigerian continental shelf. All the metals detected except Zinc were below the values recommended by FAO and WHO. All the metals estimated had health quotient and ecological risk index that were less than one. This implies that the entire population would not experience the hazard of heavy metal ( $\mathrm{Cd}, \mathrm{Cu}, \mathrm{Fe}, \mathrm{Pb}, \mathrm{Ni}, \mathrm{Mn}$, and $\mathrm{Zn}$ ) in later life due to the consumption of $N$. hastatus. It equally indicated that the shrimp posed no ecological risk in the Nigerian continental shelf. Hence, the entire human population who consumes/utilize $N$. hastatus can continually depend on the supply of safe $N$. hastatus from the Ondo axis of the Nigerian continental shelf.

\section{ACKNOWLEDGMENTS}

The authors appreciate the contributions of Dr Adewale Adeniji of the Department of Crop Science and Horticulture, Federal University Oye-Ekiti, Nigeria for his suggestion in enhancing the scope of this work. We equally appreciate the Central Research Laboratory of the Federal University of Technology Akure for their support during the analytical sections.

\section{REFERENCES}

Abubakar, A. U.; A. Ekwumemgbo, P. A.; and Okunola O. J. (2014). Evaluation of Heavy Metals Concentration in Imported Frozen Fish Trachurus Murphyi Species Sold in Zaria Market, Nigeria. American Journal of Chemistry 4(5): 137-154.

Ajala, A. S. and Oyategbe, A.O. (2013). Influence of Packaging and Storage on Nutritional Quality of White Shrimp (Penaeus vannamei), International Journal of Advanced Scientific and Technical Research 3(2):232-238.

Ajani, E. G.; Bello, O. B.; and Osowo, O. (2013). Comparative condition factor of two Penaeid shrimps, Peneaus notialis (Pink shrimp) and Peneaus monodon (Tiger shrimp) in a coastal state, Lagos, South West Nigeria. Nat Sci J 11 (4):1-3.

Ajibare A. O.; Olawusi-Peters O.O.; and Ayeku P.O. (2018). Bioaccumulation of Some Heavy Metals in the Cephalothorax and Abdomen of Nematopalaemon hastatus in the Coastal Waters of Ondo State, Nigeria, IOSR Journal of Agriculture and Veterinary Science (IOSR-JAVS) 11 (6): 32-38

Ajibare, A.O. (2018). Impacts of Anthropogenic Activities on the Ecological Status of Shrimps (Nematopalaemon hastatus and Farfantepenaeus notialis) in Coastal Waters of Ondo State, Nigeria. A Thesis Submitted to the School of Post Graduate Studies, Federal University of Technology, Akure, Nigeria in partial fulfillment of the requirements for the award of Doctor of Philosophy (Ph.D) in Fisheries Management. 327pp. 
Ajibare, A.O.; Olawusi-Peters, O.O; and Bello-Olusoji, O.A. (2017). Effects of Seasons on the Length-Weight Relationship and Condition Factor of two Brackish Water Shrimps in Ondo State, Nigeria. Nigerian Journal of Agriculture, Food and Environment. 13(3):52-58.

Akinwumi, F. O.; Akinwumi, I. O.; and Ogundahunsi, O. A. (2011). Characterization of Artisanal Fishery in the Coastal Area of Ondo State, Nigeria. International Research Journal of Agricultural Science and Soil Science, 1(3):83-89.

Alhaji, T. A.; Jim-Saiki L. O.; Giwa, J. E.; Adedeji A. K.; and Obasi E.U. (2015). Infrastructure Constraints in Artisanal Fish Production in the Coastal Area of Ondo State, Nigeria, International Journal of Research in Humanities and Social Studies, 2(5):22-29.

Baboli M. J.; Velayatzadeh, M. (2013). Determination of heavy metals andtrace elements in the muscles of marine shrimp, Fenneropenaeus merguiensis from persian gulf, Iran. J. Anim. Plant. Sci. 23, (3), 786.

Balfour, S. T.; Badrie, N.; Chang Yen, I; and Chatergoon, L. (2014). Microbiological, physical and sensory quality of marine shrimp (Peneaus spp.) sold by vendors in Trinidad, West Indies, International Food Research Journal, 21(4):1279-1288.

Bayode, O. J. A.; Adewunmi, E. A.; and Odunwole, S. (2011). Environmental Implications of Oil Exploration and Exploitation in the coastal region of Ondo State, Nigeria: A Regional Planning Appraised. Journal of Geography and Regional Planning, 5 (18):30-38.

Bello, B. K. (2013). Effect of Processing Method on the Proximate and Mineral Composition of Prawn (Penaeus Notialis), Journal of Global Biosciences, 2(2): 42-46.

Bin-Mokhtar, M.; A. Zaharin Aris.; V. Munusamy. and S. Mangala Praveena (2009). Assessment Level of heavy metals in Penaeus Monodon and Oreochromis Spp in Selected Aquaculture Ponds of High Densities Development Area. European Journal of Scientific Research, 30 (3): 348-360.

Bolwig, S.; Stefano, P.; Andries, D. T.; Riisgaard, L. and Halberg, N. (2008). Integrating Poverty Gender and Environmental Concerns into Value Chain Analysis. Copenhagen: Danish Institute for International Studies.

Camara, F.; M.A. Amaro.; R. Barbera. and G. Clemente (2005). Bio accessibility of minerals in school meals: comparison between dialysis and solubility methods. Food Chemistry, 92: 481-489.

Christensen, J. H.; Duedahl-Olesen, L. J. H.; Højgardc, A.; Granby, K. and TimmHeinrich, M. (2010). Influence of smoking parameters on the concentration of polycyclic aromatic hydrocarbons (PAHs) in Danish smoked fish. Food Addit. Contam. , 9 1294-1305.

Christensen, J. H.; Duedahl-Olesen, L. J. H.; Højgardc, A.; Granby, K. and TimmHeinrich, M. (2010). Influence of smoking parameters on the concentration of polycyclic aromatic hydrocarbons (PAHs) in Danish smoked fish. Food Addit. Contam. , 9 1294-1305.

Food and Agriculture Organization. (2007). Fisheries and Aquaculture Department. The State of Worlds Fisheries and Aquaculture 2006.Food and Agriculture Organization of the United Nations. Rome: Electronic Publishing Policy and Support Branch. 
Gendy A. E.; Farraj S. A. and Hedeny, M. E. (2015). Heavy Metal Concentrations in Tissues of the Shrimp Penaeus semisulcatus (De Haan, 1844) From Jazan, Southern Red Sea Coast of Saudi Arabia, Pakistan J. Zool., vol. 47(3):671677.

Gokoglu, N. and Yerlikaya, P. (2008). Inhibition effects of grape seed extracts on melanosis formation in shrimp (Parapenaeus longirostris). International Journal of Food Science \& Technology 43 (6): 1004- 1008.

Heidarieh, M.; Maragheh, M.G.; Shamami, M.A.; Behgar, M.; Ziaei, F. And Akbari, Z., (2013). Evaluate of heavy metal concentration in shrimp (Penaeus semisulcatus) and crab (Portunus pelagicus) with INAA method. Springer Plus., 2: 1-5.

Isibor, P. O. and Imoobe, T. O. T. (2017). Comparative Analysis of Contaminability between C. gariepinus and T. mariae. Annual Research and Review in Biology. 16(5): 1-14.

Kpoclou E. Y.; Anihouvi V. B.; Scippo M. L. and Hounhouigan J. D. (2013). Preservation practices and quality perception of shrimps along the local merchandising chain in Benin, African Journal of Agricultural Research, 8(26),3405-3414.

Kulcu A.M.; Ayas D.; Koşker A.R. and Yatkin K. (2014). The Investigation of Metal And Mineral Levels of Some Marine Species From the Northeastern Mediterranean Sea. Mar Biol. Oceanogr. 3, 2,

Macfadyen, M.; Nasr Allah, M.; Kenawy, D.; Ahmed, M.; Hebicha, H.; Diab, A.; Hussein, S.; Abouzied, R. and Naggar, G. (2011). Value Chain Analysis of Eyptian Aquaculture. Penang, Malaysia: World Fish Center, 88pp.

Matarr, B.; James, T. and Ousman, D. (2010). Artisanal Shrimp (Prawn) Fishery Value Chain Assessment. Coastal Resources Center: University of Rhode Island, 39pp.

National Population Commission, (2006). Federal Republic of Nigeria 2006 Population and Housing Census, 371pp.

Navghan, M.; Ranjan, N. K.; Stanzin, G. and Hoilenting R., H. (2017). Value Chain Analysis of Farmed Shrimp in Navsari District of Gujarat. International Journal of Pure and Applied Bioscience, 5(6):352-357.

Oksuz, A.; Ozilmaz, A.; Aktas, M.; Gercek, G. and Motte, J. (2009). A Comparative Study on Proximate, Mineral and Fatty Acid Compositions of Deep Seawater Rose Shrimp (Parapenaeus longirostris) and Red Shrimp (Plesionika martia). J. Anim. Vet. Adv., 8 (1): 183-189.

Olawusi-Peters O. O.; Ajibare A. O. and Bello-Olusoji O. A. (2014). Length-weight relationship and condition factor of shrimps in coastal waters of Ondo state, South West, Nigeria, International Journal of Fisheries and Aquatic Studies; 1(3): 137-142

Olawusi-Peters, O. O. and Ajibare, A. O. (2014). Species richness, diversity and abundance of some Decapod Crustaceans in coastal waters of Ondo State, South West, Nigeria. Int. J. of Fauna and Bio Studies, 1 (5):44-51.

Olgunoglu M.P.; Olgunoglu İ.A. and Bayhan K. (2015). Heavy metal concentrations $(\mathrm{Cd}, \mathrm{Pb}, \mathrm{Cu}, \mathrm{Zn}, \mathrm{Fe})$ in female and male species of giant red shrimp (Aristaeomorpha foliacea Risso 1827) from Mediterranean Sea. Pol. J. Environ. Stud. 24, (2), 631-647. 
Oluyemi, E. A. and Olabanji I. O. (2011). Heavy metals determination in some species of frozen fish soldat Ile-Ife main market. Ife Journal of Science, 13, (2): 86 - 93.

Okunola O. J.; Alhassan Y.; Yebpella G. G.; Uzairu A.; Tsafe A. I.; Abechi E. and Apene S. E. (2011). Risk assessment of using coated mobile recharge cards in Nigeria. J. of Env. Chem. and Ecotoxic., 3, (4): 80 - 85.

Sajjad K.; Robina F.; Shagufta S.; Mohammad A. K. and Maria Sadique. (2009). Health risk assessment of heavy metals for population via consumption of vegetables. World Applied Sciences Journal, 6, (12): 1602 - 1606.

Shehu L.A.; Ayodele B.; Abubakar B.; Osowo O.D. and Bello, B.O. (2013). Effects of Hot Smoking and Sun Drying Processes on Nutritional Composition of Giant Tiger Shrimp (Penaeus monodon, Fabricius, 1798) , Pol. J. Food Nutr. Sci., 63 (4):227-237.

Soegianto, A.; Irawan, B. and Hamami, (2008). Bioaccumulation of Heavy Metals in Aquatic Animals Collected from Coastal Waters of Gresiko Indonesia, Asian Journal of Water, Environment and Pollution, 6 (2): 95-100.

Solarin, B. B.; Williams, A. B.; Hamzat, M. B.; Rabiu, A.; Oguntade, O. R.; Bolaji, D. A. and Oramadike, M. (2010). Report on survey of fish and other living resources of the Nigerian coastal waters conducted Lagos: Nigeria Institute of Oceanography and Marine Research.

Tawfik, M.S. (2013). Impact of Different Cooking Processes on Proximate and Metal Composition of Fish and Shrimp, Journal of Food Technology, 11(4-6):95102.

Udo P. J. and Opeh P.B. (2013). The Biochemical Analysis of the Carcass of Two West African Caridean Shrimps: Macrobrachium Vollenhovenii (Herklot's, 1857) and Macrobrachium Macrobrachion (Herklot's, 1951) of the Great Kwa River, Nigeria, International Journal of Science and Research (IJSR), 2(12):312-314

United Nations Environmental Protection Agency. (2015). The value of Coastal Ecosystem [Online]. Available: http://web.unep.org/coastal-eba/it/node/631 [Accessed 2nd March 2018].

United Nations. (2015). Transforming our World: The 2030 Agenda for Sustainable Development, New York, 36pp.

World Health Organization (2005). Background document for development of WHO guidelines for nickel in drinking-water quality and fish. WHO/Sde/Wsh/05.08/55 English only.

Yarsan E.; Yipel M.; Yipel F.A. and Dikmen B. (2013). Accumulation of Nonessential Potentially Toxic Trace Elements in Some Economically Important Seafood Species of Mediterranean. Kafkas Univ. Vet. Fak. Derg. 20(2): 185. 